\title{
Response of Different Sources of Potassium on Biochemical Quality of Litchi cv. Deshi
}

\author{
Karanjeev Kumar, Kumari Madhumala*, Sanjay Sahay and Feza Ahmad \\ Department of Fruit and Fruit Technology, BAU Sabour Bhagalpur, India \\ *Corresponding author
}

Keywords

Litchi, Marble,

Stone, Sugar,

Anthocyanin

Article Info

Accepted:

15 January 2020

Available Online:

10 February 2020

\section{A B S T R A C T}

Litchi (Litchi chinensis Sonn.) recognized as "Queen of the fruits". It is an important sub- tropical evergreen fruit crop belongs to the family Sapindaceae. The present investigation was carried out during the year 2019. Ten years old uniformly grown "Deshi" litchi plants established at Bihar Agricultural University Sabour Fruit Research Station, were sprayed with $\mathrm{K}_{2} \mathrm{SO}_{4}$ and $\mathrm{KCl} @ 0 \%, 1 \%$ and 2\% at two different stages i.e. Marble and Stone hardening stage. The plants treated with potassium as foliar feeding significantly improved fruit quality characteristics viz. TSS, TSS/acid ratio, total sugars, reducing sugar, ascorbic acid were also enhanced with marble and stone hardening stage with sprays of different concentrations of potassium fertilizers over untreated trees. Anthocyanin content higher with $\mathrm{K}_{2} \mathrm{SO}_{4}$ application at stone hardening stage. So, it is concluded that $\mathrm{K}_{2} \mathrm{SO}_{4} @ 1 \%$ and $2 \%$ at stone hardening stage significantly improved total sugar, reducing sugar and anthocyanin litchi cv. Deshi.

\section{Introduction}

Litchi (Litchi chinensis Sonn.) recognized as "Queen of the fruits". It is an important subtropical evergreen fruit crop belongs to the family Sapindaceae. It is native of south China and was introduced in India by the end of 17 th century to explore the possibilities of litchi cultivation in India due to available of conducive temperature and climatic requirements. Litchi crop is widely distributed in the tropics and warm subtropics of the world. It is a highly perishable nature and is used in the form of fresh fruit and value added products i.e. RTS, squash, dry nut etc. It also contains 40-90 mg vitamin-C/100 g edible portion, $0.9 \%$ protein, $0.3 \%$ fat, $0.42 \%$ pectin and $0.7 \%$ minerals $(\mathrm{Ca}, \mathrm{P}, \mathrm{Fe})$. Its skin is rich in insoluble fiber which prevents rectum cancer, diabetes. Wang et al., (2010) reported that water soluble alcohol extracted from litchi skin significantly inhibited in vitro growth of human hepatoma cells and suppressed cancer development particularly effective in the breast cancer. Its skin also contains free radical scavenging compounds 
like ascorbic acid, carotenoids, polysaccharides (Yang et al., 2006) and phenolic substances flavonoids (flavonols and anthocyanins) and phenolic acids.

In India litchi fruit production $497 \mathrm{MT}$ and productivity $7.02 \mathrm{MT} / \mathrm{ha}$ is obtained from an area of 78 thousand ha (Anonymous 2017). Major growing state are Bihar, West Bengal, Assam and Jharkhand and to a small extent to a Tripura, Punjab, Uttarakhand and Odisha. It is cultivated on 32 thousand ha area with annual production of 300 MT and productivity 9.37 thousand MT/ha in Bihar state (Anonymous 2017) and approximately 90 percent of the total area under litchi cultivation is mainly Champaran, Siwan, Darbhanga, Purniya, Bhagalpur, Saharsa, Araria, Munger, Mdhubani, Madhepura and Begusarai. Litchi has ensure high economic productivity and retain the optimum nutrients in the soil at the desired level correct doses of manures and fertilizers must be applied on the basis of long term fertilizer experiments and choose of reliable diagnostic tools (Bhargava et al., 1993). It is postulated that $10 \mathrm{MT}$ litchi fruits annually remove nearly $67 \mathrm{~kg} \mathrm{~N}, 16 \mathrm{~kg}$ $\mathrm{P}_{2} \mathrm{O}_{5}$ and $73 \mathrm{~kg} \mathrm{~K} \mathrm{O}$ from the soil. It is therefore essential that litchi trees should be supplied with adequate nutrients for fruit production as limited supply of macro and micro nutrients in the soil is responsible for poor fruit yield and quality (Menzel and Simpson 1987). Yang et al., (2015) conclude that fruit potassium fertilizer $(40 \%)$ should also be applied during the fruit enlargement period to promote litchi fruit expansion and to improve litchi yield and quality.

Likely Menzel and Kirby (2001) also reported that potassium enhances cell hydration and its deficiency causes tissue dehydration and act as the main osmotic solute in the plants for stomata functions. Potassium is involved in the translocation of sugars, formation of carbohydrates and regulates root hydraulic conductivity and provides resistance against pest, diseases, drought and stress (Imas and Bansal, 1999). Southwick et al., (1996) suggested that potassium intake from foliar feeding is more efficient than soil application. Litchi cv. Rose Scented under Uttrakhand conditions Kumar Kumar (2004) confirmed that three pre harvest foliar sprays of "MultiK”(1.0\%)@15, 30 and 45 days after fruit set considerably produced fruits with higher TSS (18.0\%), total sugars (12.4\%), TSS/acid blend ratio (28.6), juice\%, ascorbic acid content (34.9 mg / $100 \mathrm{~g}$ pulp) and lower $(0.63 \%)$ acid than the control. Two preharvest foliar sprays of Polyfeed (19:19:19) onlitchi plants at the interval of 15 and 45 days after fruit set effectively produced fruits with maximum fruit weight, aril weight, juice $\%$, TSS, total sugars, reducing sugars, TSS/acid ratio, sugar/ acid ratio and ascorbic acid and minimum acidity content (Singh et al., 2007).

\section{Materials and Methods}

The material and methods employed during the investigation are described here under. The present studies were carried out on 10 years old fully mature uniform healthy plants of litchi cultivar "Deshi" planted at $10.0 \mathrm{~m} \mathrm{x}$ $10.0 \mathrm{~m}$. The uniform cultural practices were given to all the plants as per recommendation of Package and Practices for Fruit Crops of Bihar Agricultural University Sabour. The experiment was layout by Factorial Randomized Block Design (FRBD) and plants were (in addition to soil application of recommended doses of fertilizers) sprayed with different concentrations $0 \%, 1 \%$, and $2 \%$ $\left(\mathrm{D}_{0}, \mathrm{D}_{1}\right.$, and $\mathrm{D}_{2}$ respectively) of $\mathrm{K}_{2} \mathrm{SO}_{4}(48 \%)$ and $\mathrm{KCl}(60 \%)\left(\mathrm{K}_{1}, \mathrm{~K}_{2}\right.$ respectively) at two different sub treatments stages i.e. Marble stage $\left(S_{1}\right)$ and Stone hardening stage $\left(S_{2}\right)$. Each treatment was replicated three times. The plants were sprayed with hand operated Knapsack sprayer during early morning hours 
after dissolving calculated dose of respective treatment.

\section{Total soluble solids (TSS)}

The total soluble solids of each sample fruit was estimated using digital hand held Refractometer at $20^{\circ} \mathrm{C}$ and the results were expressed as degree brix ( $\left.{ }^{\circ} \mathrm{Brix}\right)$.

\section{Titrable Acidity (\%)}

Titrable acidity was determined using titration method (Rangana, 2010). For this $2 \mathrm{~g}$ of fruit sample was weighed and added to $50 \mathrm{ml}$ distilled water. This was thoroughly mixed and then filtered. The filtered sample was titrated against $0.1 \mathrm{~N} \mathrm{NaOH}$ using a few drops of $1 \%$ phenolphthalein solution as indicator. The observed titre value was used for calculating acidity and the results were expressed as (\%).

Acidity $(\%)=$

$\frac{0.0067 \times \text { Volume of } \mathrm{NaOH} \text { used }}{\text { Volume of juice taken }} \times 100$

\section{TSS/Acid ratio}

TSS/acid ratio was calculated by dividing the value of total soluble solids with that of the corresponding total titrable acidity.

\section{Total sugars( $\%)$}

The estimation of total and reducing sugars was done by using method suggested by Lane and Eynon (AOAC, 1990).

\section{Ascorbic acid content (mg/100 g)}

Ascorbic acid was quantitatively determined by 2, 6-dichlorophenol indophenol dye method as described by Jones and Hughes (1983) with slight modifications.

\section{Total Anthocyanin (mg/100g)}

Ten gram of the sample was crushed with $10 \mathrm{ml}$ of ethanolic $\mathrm{HCl}$ with the help of pestle and mortar and transferred into $50 \mathrm{ml}$ conical flask using $10 \mathrm{ml}$ ethanolic $\mathrm{HCl}$ for washing. The solution was stored overnight afterwards solution was filtered with Whatman No.1 filter paper. Final volume was made up to 100 $\mathrm{ml}$ and stored in dark for $2 \mathrm{hs}$. Absorbance was recorded at $535 \mathrm{~nm}$.

Total anthocyanin $(\mathrm{mg} / 100 \mathrm{~g})=$

OD $\mathrm{x}$ dilution $\mathrm{x}$ total volume made up

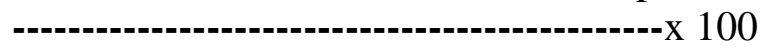

Weight of sample x e

Where $\mathrm{e}=98.2$ (absorbance of a solution containing $0.1 \mathrm{mg} / \mathrm{ml}$ anthocyanin)

\section{Results and Discussion}

Litchi fruit acidity has been reduced with the foliar application of potassium sulphate as compared to potassium chloride. As far as dose of potassium is concerned, the percentage of acidity increases with the increase in potassium dose.

However, the potassium application at stone hardening stage favour in reduction of total acidity in litchi fruits. The minimum fruit acidity was observed in control followed by $1 \%$ and $2 \%$. The lowest $(0.31 \%)$ fruit acidity was noted with the application of $600 \mathrm{~g} \mathrm{~K}_{2} \mathrm{O}$ in two splits at 15 days after fruit set and 30 days before flowering in litchi cultivar "Bombai" as reported by Pathak and Mitra (2010).

The maximum TSS was found in $\mathrm{K}_{2} \mathrm{SO}_{4}$ @ 2\% applied at marble stage. The increase in TSS content with potassium application due to synthesis of more carbohydrate and its translocation from leaves to fruits. 


\begin{tabular}{|c|c|c|}
\hline S. No. & Treatment symbol & Treatment detail \\
\hline $\mathbf{1}$ & $\mathbf{S}_{\mathbf{1}} \mathbf{K}_{\mathbf{1}} \mathbf{D}_{\mathbf{0}}$ & Potassium sulphate @ 0\% at Marble stage \\
\hline $\mathbf{2}$ & $\mathbf{S}_{\mathbf{1}} \mathbf{K}_{\mathbf{1}} \mathbf{D}_{\mathbf{1}}$ & Potassium sulphate @ 1\% at Marble stage \\
\hline $\mathbf{3}$ & $\mathbf{S}_{\mathbf{1}} \mathbf{K}_{\mathbf{1}} \mathbf{D}_{\mathbf{2}}$ & Potassium sulphate @ 2\% at Marble stage \\
\hline $\mathbf{4}$ & $\mathbf{S}_{\mathbf{1}} \mathbf{K}_{\mathbf{2}} \mathbf{D}_{\mathbf{0}}$ & Potassium chloride @ 0\% at Marble stage \\
\hline $\mathbf{5}$ & $\mathbf{S}_{\mathbf{1}} \mathbf{K}_{\mathbf{2}} \mathbf{D}_{\mathbf{1}}$ & Potassium chloride @ 1\% at Marble stage \\
\hline $\mathbf{6}$ & $\mathbf{S}_{\mathbf{1}} \mathbf{K}_{\mathbf{2}} \mathbf{D}_{\mathbf{2}}$ & Potassium chloride @ 2\% at Marble stage \\
\hline $\mathbf{7}$ & $\mathbf{S}_{\mathbf{2}} \mathbf{K}_{\mathbf{1}} \mathbf{D}_{\mathbf{0}}$ & Potassium sulphate @ 0\% at Stone stage \\
\hline $\mathbf{8}$ & $\mathbf{S}_{\mathbf{2}} \mathbf{K}_{\mathbf{1}} \mathbf{D}_{\mathbf{1}}$ & Potassium sulphate @ 1\% at Stone stage \\
\hline $\mathbf{9}$ & $\mathbf{S}_{2} \mathbf{K}_{\mathbf{1}} \mathbf{D}_{\mathbf{2}}$ & Potassium sulphate @ 2\% at Stone stage \\
\hline $\mathbf{1 0}$ & $\mathbf{S}_{\mathbf{2}} \mathbf{K}_{\mathbf{2}} \mathbf{D}_{\mathbf{0}}$ & Potassium chloride @ 0\% at Stone stage \\
\hline $\mathbf{1 1}$ & $\mathbf{S}_{\mathbf{2}} \mathbf{K}_{\mathbf{2}} \mathbf{D}_{\mathbf{1}}$ & Potassium chloride @ 1\% at Stone stage \\
\hline $\mathbf{1 2}$ & $\mathbf{S}_{\mathbf{2}} \mathbf{K}_{\mathbf{2}} \mathbf{D}_{\mathbf{2}}$ & Potassium chloride @ 2\% at Stone stage \\
\hline & & \\
\hline
\end{tabular}

Table.1 Meteorological data (2018-19)

\begin{tabular}{|c|c|c|c|c|c|c|}
\hline Months & \multicolumn{2}{|c|}{ Temperature( $\left.{ }^{\mathbf{0}} \mathbf{C}\right)$} & \multicolumn{2}{|c|}{$\begin{array}{r}\text { Relative Humidity } \\
\mathbf{( \% )}\end{array}$} & $\begin{array}{c}\text { Wind } \\
\text { Speed } \\
(\mathbf{K m} / \mathbf{h r})\end{array}$ & $\begin{array}{c}\text { Rainfall } \\
(\mathbf{m m})\end{array}$ \\
\cline { 2 - 6 } & Max. & Min. & $\mathbf{7 . 0 0} \mathbf{a m}$ & $\mathbf{2 . 0 0} \mathbf{~ p m}$ & \\
\hline Oct. 2018 & 31.27 & 19.75 & 89.58 & 72.84 & 2.46 & 2.53 \\
\hline Nov. 2018 & 29.56 & 12.85 & 88.37 & 61.27 & 0.00 & 1.89 \\
\hline Dec. 2018 & 24.21 & 7.44 & 89.26 & 59.65 & 0.36 & 2.57 \\
\hline Jan. 2019 & 23.01 & 5.63 & 89.58 & 54.23 & 0.14 & 3.59 \\
\hline Feb. 2019 & 25.18 & 10.08 & 88.04 & 60.75 & 1.51 & 4.76 \\
\hline March 2019 & 30.47 & 15.44 & 83.42 & 62.32 & 0.04 & 2.98 \\
\hline April 2019 & 33.56 & 21.46 & 77.93 & 57.20 & 1.27 & 3.21 \\
\hline May 2019 & 38.78 & 24.28 & 75.74 & 50.42 & 1.97 & 2.55 \\
\hline Average & 29.51 & 14.62 & 85.24 & 59.83 & 0.97 & 3.01 \\
\hline
\end{tabular}


Table.2 Main effect of foliar application of different sources of Potassium, doses and stages with respect to TSS, Acidity, Ascorbic acid on litchi cv. Deshi

\begin{tabular}{|c|c|c|c|c|}
\hline Treatments & $\begin{array}{c}\text { TSS } \\
\left({ }^{\mathbf{0}} \text { Brix }\right)\end{array}$ & $\begin{array}{c}\text { Acidity } \\
(\%)\end{array}$ & TSS/Acidity & $\begin{array}{l}\text { Ascorbic acid } \\
\text { (mg/100 g) }\end{array}$ \\
\hline \multicolumn{5}{|c|}{ Source of Potassium (Main effect) } \\
\hline Potassium sulphate $\left(K_{1}\right)$ & 18.62 & 0.48 & 39.21 & 38.81 \\
\hline Potassium chloride $\left(K_{2}\right)$ & 18.23 & 0.60 & 30.78 & 40.43 \\
\hline $\mathrm{SE} \mathbf{m} \pm$ & 0.21 & 0.01 & 0.57 & 0.47 \\
\hline $\mathrm{CD}(\mathrm{P}=\mathbf{0 . 0 5})$ & NS & 0.02 & 1.67 & 1.39 \\
\hline \multicolumn{5}{|c|}{ Dose of potassium (Main effect) } \\
\hline @ $0 \%$ & 17.29 & 0.48 & 36.46 & 41.38 \\
\hline @ 1\% & 18.77 & 0.57 & 34.55 & 39.23 \\
\hline @ 2\% & 19.22 & 0.58 & 33.97 & 37.65 \\
\hline $\mathrm{SE} \mathbf{m} \pm$ & 0.26 & 0.01 & 0.70 & 0.58 \\
\hline $\mathrm{CD}(\mathrm{P}=\mathbf{0 . 0 5})$ & 0.76 & 0.02 & 2.05 & 1.70 \\
\hline \multicolumn{5}{|c|}{ Stage of application (Main effect) } \\
\hline Marble stage $\left(\mathbf{S}_{1}\right)$ & 18.51 & 0.58 & 32.91 & 38.46 \\
\hline Stone hardening stage $\left(\mathbf{S}_{2}\right)$ & 18.42 & 0.51 & 37.07 & 40.78 \\
\hline $\mathrm{SE} \mathbf{m} \pm$ & 0.21 & 0.01 & 0.57 & 0.47 \\
\hline $\mathrm{CD}(\mathbf{P}=\mathbf{0 . 0 5})$ & NS & 0.02 & 1.67 & 1.39 \\
\hline
\end{tabular}


Table.2 Interaction effect of foliar application of different sources of Potassium, doses and stages with respect to TSS, Acidity, Ascorbic acid on litchi cv. Deshi

\begin{tabular}{|c|c|c|c|c|c|}
\hline \multicolumn{2}{|l|}{ Interaction effect } & TSS $\left({ }^{\circ}\right.$ Brix $)$ & Acidity(\%) & TSS/Acidity & $\begin{array}{c}\text { Ascorbic acid } \\
(\mathrm{mg} / 100 \mathrm{~g})\end{array}$ \\
\hline \multicolumn{6}{|c|}{$\underline{\text { Interaction effect (K X D) }}$} \\
\hline \multirow{3}{*}{$\begin{array}{l}\text { Potassium sulphate } \\
\left(\mathbf{K}_{1}\right)\end{array}$} & $@ 0 \%$ & 17.47 & 0.45 & 38.95 & 41.57 \\
\hline & $@ 1 \%$ & 19.64 & 0.48 & 42.11 & 37.86 \\
\hline & $@ 2 \%$ & 18.76 & 0.52 & 36.55 & 37.01 \\
\hline \multirow{3}{*}{$\begin{array}{l}\text { Potassium chloride ( } \\
\left.\mathbf{K}_{2}\right)\end{array}$} & $@ 0 \%$ & 17.11 & 0.51 & 33.96 & 42.39 \\
\hline & $@ 1 \%$ & 17.90 & 0.67 & 27.00 & 40.60 \\
\hline & $@ 2 \%$ & 19.67 & 0.64 & 31.39 & 38.30 \\
\hline \multicolumn{2}{|l|}{ SE $\mathbf{m} \pm$} & 0.37 & 0.01 & 0.99 & 0.82 \\
\hline \multicolumn{2}{|l|}{$\mathrm{CD}(\mathrm{P}=0.05)$} & 1.08 & 0.03 & 2.89 & NS \\
\hline \multicolumn{6}{|l|}{ Interaction effect $(\mathrm{K} \times \mathrm{S})$} \\
\hline \multirow{2}{*}{$\begin{array}{l}\text { Potassium Sulphate } \\
\left(\mathrm{K}_{1}\right)\end{array}$} & $\operatorname{Marble}\left(\mathrm{S}_{1}\right)$ & 18.63 & 0.51 & 36.69 & 36.24 \\
\hline & Stone $\left(\mathrm{S}_{2}\right)$ & 18.S62 & 0.45 & 41.72 & 41.98 \\
\hline \multirow{2}{*}{$\begin{array}{l}\text { Potassium Chloride } \\
\left(\mathbf{K}_{2}\right)\end{array}$} & $\operatorname{Marble}\left(\mathrm{S}_{1}\right)$ & 18.39 & 0.65 & 29.14 & 40.67 \\
\hline & Stone $\left(\mathrm{S}_{2}\right)$ & 18.06 & 0.56 & 32.43 & 40.18 \\
\hline \multicolumn{2}{|l|}{ SE $\mathbf{m} \pm$} & 0.30 & 0.01 & 0.81 & 0.67 \\
\hline \multicolumn{2}{|l|}{$\mathrm{CD}(\mathrm{P}=\mathbf{0 . 0 5})$} & NS & NS & NS & 1.97 \\
\hline \multicolumn{6}{|c|}{ Interaction effect (S X D) } \\
\hline \multirow[t]{3}{*}{ Marble stage $\left(\mathbf{S}_{\mathbf{1}}\right)$} & $@ 0 \%$ & 16.97 & 0.46 & 37.56 & 40.46 \\
\hline & $@ 1 \%$ & 18.51 & 0.66 & 28.04 & 39.25 \\
\hline & $@ 2 \%$ & 20.05 & 0.63 & 31.82 & 35.66 \\
\hline \multirow{3}{*}{$\begin{array}{l}\text { Stone hardening stage } \\
\left(\mathbf{S}_{2}\right)\end{array}$} & $@ 0 \%$ & 17.61 & 0.50 & 35.35 & 43.50 \\
\hline & @ 1\% & 19.03 & 0.52 & 38.78 & 39.21 \\
\hline & @2\% & 18.38 & 0.50 & 37.09 & 39.65 \\
\hline \multicolumn{2}{|l|}{ SE $\mathbf{m} \pm$} & 0.37 & 0.01 & 0.99 & 0.82 \\
\hline \multicolumn{2}{|l|}{$\mathrm{CD}(\mathrm{P}=\mathbf{0 . 0 5})$} & 1.08 & 0.03 & 2.89 & NS \\
\hline
\end{tabular}


Table.3 Main effect of foliar application of different sources of Potassium, doses and stages with respect to TS, RS, NRS, Anthocynin in litchi cv. Deshi

\begin{tabular}{|c|c|c|c|c|}
\hline Treatment & $\begin{array}{c}\text { Total sugar } \\
(\%)\end{array}$ & $\begin{array}{c}\text { Reducing sugar } \\
(\%)\end{array}$ & $\begin{array}{l}\text { Non Reducing } \\
\text { sugar }(\%)\end{array}$ & $\begin{array}{c}\text { Anthocynin } \\
(\mathrm{mg} / 100 \mathrm{~g})\end{array}$ \\
\hline \multicolumn{4}{|c|}{ Source of Potassium (Main effect) } & \\
\hline $\begin{array}{l}\text { Potassium } \\
\text { sulphate }\left(\mathbf{K}_{1}\right)\end{array}$ & 15.62 & 11.44 & 3.97 & 32.43 \\
\hline $\begin{array}{l}\text { Potassium } \\
\text { chloride }\left(K_{2}\right)\end{array}$ & 15.03 & 11.11 & 3.72 & 31.64 \\
\hline SE $\mathbf{m} \pm$ & 0.17 & 0.11 & 0.04 & 0.36 \\
\hline $\mathrm{CD}(\mathbf{P}=\mathbf{0 . 0 5})$ & 0.50 & 0.31 & 0.10 & NS \\
\hline \multicolumn{4}{|c|}{ Dose of potassium (Main effect) } & \\
\hline @ 0\% & 15.52 & 10.70 & 4.58 & 30.03 \\
\hline @ 1\% & 15.35 & 11.81 & 3.36 & 32.51 \\
\hline @ 2\% & 15.11 & 11.32 & 3.59 & 33.56 \\
\hline SE $\mathbf{m} \pm$ & 0.21 & 0.13 & 0.04 & 0.44 \\
\hline $\mathrm{CD}(\mathrm{P}=0.05)$ & NS & 0.38 & 0.13 & 1.29 \\
\hline \multicolumn{4}{|c|}{ Stage of application (Main effect) } & \\
\hline Marble stage $\left(\mathbf{S}_{1}\right)$ & 15.10 & 10.91 & 3.98 & 31.29 \\
\hline Stone stage $\left(\mathbf{S}_{2}\right)$ & 15.55 & 11.65 & 3.71 & 32.78 \\
\hline SE $\mathbf{m} \pm$ & 0.17 & 0.11 & 0.04 & 0.36 \\
\hline $\mathrm{CD}(\mathrm{P}=\mathbf{0 . 0 5})$ & NS & 0.31 & 0.10 & 1.05 \\
\hline
\end{tabular}


Table.4 Interaction effect of foliar application of different sources of Potassium, doses and stages with respect to TS, RS, NRS, Anthocyaninin litchi cv. Deshi

\begin{tabular}{|c|c|c|c|c|c|}
\hline \multicolumn{2}{|c|}{ Interaction effect } & $\begin{array}{c}\text { Total } \\
\operatorname{sugar}(\%)\end{array}$ & $\begin{array}{r}\text { Reducing } \\
\text { sugar }(\%)\end{array}$ & $\begin{array}{c}\text { Non } \\
\text { Reducing } \\
\text { sugar }(\%)\end{array}$ & $\begin{array}{c}\text { Anthocyanin } \\
\text { (mg/100g) }\end{array}$ \\
\hline \multicolumn{6}{|c|}{ Interaction effect(K X D) } \\
\hline \multirow{3}{*}{$\begin{array}{l}\text { Potassium } \\
\text { sulphate }\left(\mathbf{K}_{1}\right)\end{array}$} & $@ 0 \%$ & 15.48 & 11.08 & 4.17 & 30.41 \\
\hline & @1\% & 15.49 & 11.66 & 3.64 & 33.05 \\
\hline & $@ 2 \%$ & 15.90 & 11.59 & 4.09 & 33.84 \\
\hline \multirow{3}{*}{$\begin{array}{l}\text { Potassium } \\
\text { chloride }\left(K_{2}\right)\end{array}$} & $@ 0 \%$ & 15.57 & 10.31 & 5.00 & 29.65 \\
\hline & $@ 1 \%$ & 15.20 & 11.96 & 3.08 & 31.97 \\
\hline & $@ 2 \%$ & 14.32 & 11.06 & 3.09 & 33.29 \\
\hline \multicolumn{2}{|l|}{ SE $\mathbf{m} \pm$} & 0.29 & 0.19 & 0.06 & 0.62 \\
\hline \multicolumn{2}{|c|}{$\mathrm{CD}(\mathrm{P}=\mathbf{0 . 0 5})$} & 0.87 & 0.54 & 0.18 & NS \\
\hline \multicolumn{6}{|c|}{ Interaction effect (K X S) } \\
\hline \multirow{2}{*}{$\begin{array}{l}\text { Potassium } \\
\text { sulphate }\left(\mathbf{K}_{1}\right)\end{array}$} & Marble $\left(S_{1}\right)$ & 15.64 & 11.15 & 4.26 & 31.08 \\
\hline & $\begin{array}{l}\text { Stone } \\
\text { (S2) }\end{array}$ & 15.60 & 11.74 & 3.67 & 33.78 \\
\hline \multirow[t]{2}{*}{$\begin{array}{l}\text { Potassium } \\
\text { chloride }\left(K_{2}\right)\end{array}$} & $\begin{array}{l}\text { Marble } \\
\left(\mathrm{S}_{1}\right)\end{array}$ & 14.56 & 10.66 & 3.69 & 31.49 \\
\hline & $\begin{array}{l}\text { Stone } \\
\left(\mathrm{S}_{2}\right)\end{array}$ & 15.50 & 11.55 & 3.75 & 31.78 \\
\hline \multicolumn{2}{|l|}{ SE $\mathbf{m} \pm$} & 0.24 & 0.15 & 0.05 & 0.51 \\
\hline \multicolumn{2}{|l|}{$\mathrm{CD}(\mathrm{P}=\mathbf{0 . 0 5})$} & NS & NS & 0.15 & 1.49 \\
\hline \multicolumn{6}{|c|}{ Interaction effect (S x D) } \\
\hline \multirow{3}{*}{$\begin{array}{l}\text { Marble stage } \\
\left(\mathbf{S}_{1}\right)\end{array}$} & $@ 0 \%$ & 15.42 & 10.18 & 4.98 & 29.91 \\
\hline & @1\% & 15.15 & 11.58 & 3.39 & 31.45 \\
\hline & $@ 2 \%$ & 14.73 & 10.96 & 3.57 & 32.50 \\
\hline \multirow{3}{*}{$\begin{array}{l}\text { Stone hardening } \\
\text { stage }\left(\mathbf{S}_{2}\right)\end{array}$} & $@ 0 \%$ & 15.63 & 11.22 & 4.19 & 30.15 \\
\hline & $@ 1 \%$ & 15.54 & 12.04 & 3.33 & 33.57 \\
\hline & @2\% & 15.49 & 11.69 & 3.61 & 34.62 \\
\hline \multirow{2}{*}{\multicolumn{2}{|c|}{ SE $\mathbf{m} \pm$}} & 0.29 & 0.19 & 0.06 & 0.62 \\
\hline & & NS & NS & 0.18 & NS \\
\hline
\end{tabular}


These results are corroborated with the finding of Dilmaghani et al., (2005) who conclude that application of $\mathrm{K}$ at high rates significantly increased fruit soluble solids content in "Golden Delicious" apples and maximum TSS was found with application of $1000 \mathrm{~g} \mathrm{~K}_{2} \mathrm{O}$ per tree in "Starking Delicious" apples. Chanana and Gill (2008) observed that foliar application of $\mathrm{K}_{2} \mathrm{SO}_{4}$ substantially improved TSS and decreased the fruit acidity in "Perlette" grapes. Pathak et al., (2013) also observed that higher rates of both $\mathrm{P}$ and $\mathrm{K}$ markedly reduced the fruit acidity however, increased TSS/acid ratio.

The maximum total sugar was found with $\mathrm{K}_{2} \mathrm{SO}_{4} @ 2 \%$ and minimum with $\mathrm{KCl} @ 2 \%$. However, the dose of potassium did not showed any significant difference for total sugar. Application of potassium either at marble or stone hardening stage have any significant difference. The results are in accordance with the findings of Ahlawat and Yamdagini (1981) who observed that increased total sugar with potassium in guava fruits might be attributed to higher assimilating power of leaves over longer period resulting in increased availability of sugars to fruits. Potassium is known to enhance photophosphorylation and dark reaction of photosynthesis resulting in increased accumulation of carbohydrates. Similarly according to Taiz and Zeiger (2004) the efflux of sucrose to the apoplast is facilitated by potassium availability which thereby increases sugar translocation from source to sink tissues promoting their growth. Pathak and Mitra (2010) concluded the similar results that fruits from the plants receiving $800 \mathrm{~g}$ Potassium chloride in two splits at 15 days after fruit set and 30 days before flowering showed the maximum reducing sugar $(14.65 \%)$ content of fruit.

Various other researchers reported similar findings of increase in reducing sugar content with K application Kumar et al., (2006) in "Alphonso" mango.

The ascorbic acid content of litchi fruit has positive effect by the different source of potassium, its doses and stage of application. The interaction effect does not differ for ascorbic acid. The maximum ascorbic acid was recorded with $\mathrm{K}_{2} \mathrm{SO}_{4}$ applied at stone hardening stage. Increase in ascorbic acid with potassium is connected with improved sugar metabolism. Bhat et al., (2009) reported the maximum ascorbic acid content with foliar application of potassium sulphate (6.02 $\mathrm{mg} / 100 \mathrm{~g}$ ) and minimum under control (4.14 $\mathrm{mg} / 100 \mathrm{~g}$ ) in cherry cv. "Makhmali. Bhat et al., (2009) further stated that increases in ascorbic acid content might be attributed to higher synthesis of some metabolites and intermediate substances which promoted the synthesis of precursor of ascorbic acid. The highest anthocyanin content was observed with $\mathrm{K}_{2} \mathrm{SO}_{4}$ applied at stone hardening stage and minimum with control while as source of potassium and its concentration do not registered any significant differences. Potassium play important role in bio synthesis pathway of anthocyanin. The findings are in confirmation with the literature as suggested by Fisher and Kwong (1961) that improvement in colour was noted with application of $\mathrm{K}$ fertilization might be due to increased in carbohydrates accumulation in the fruits. In peaches Trevisan et al., (2006) reported that soil application $(1200 \mathrm{~g}$ of $\mathrm{KCl}$ $+10 \mathrm{~g} \mathrm{KCl}$ ) as foliar application combined with vegetative pruning improved red coloration of fruits.

\section{References}

Ahlawat, V.P. and Yamdagni, R. (1981). Effect of potassium sprays on quality of guava (Psidium guajava L.) cv. Sardar. AgricSci Digest 1: 213-14.

Bhargava B S, Singh H P and Chadha K L 
(1993) Role of potassium in development of fruit quality. In: $\mathrm{K} \mathrm{L}$ Chadha and O P Pareek (ed) Advances in Horticulture, Vol. 2 Fruit Crops. Pp. 947-60. Malhotra Publishing House, New Delhi.

Chanana Y R and Gill M I S (2008) High quality grapes can be produced in Punjab. ActaHort785:85-86.

Dilmaghni M R, Malakouti M J, Neilsen G H and Fallahi E (2005) Interactive effects of potassium and calcium on $\mathrm{K} / \mathrm{Ca}$ ratio and its consequences on apple fruit quality in calcareous soils of Iran. J Pl Nut., 27: 1149-62.

Fisher E G and Kwong S S (1961) The effect of potassium fertilization on fruit quality of McIntosh apple. Proc Am SocHortSci., 78: 16-23.

Kumar A and Kumar G (2004) Effect of foliar applications of water soluble fertilizer "Multi- K" on yield and quality of Litchi cv. Rose Scented. Adv Pl Sci., 17: 519-23.

Kumar N, Selvi R, Meenakshi N, Balasubramanyan S and Ebert G (2006) Foliar application of potash (SOP) on yield and quality of fruits in mango cv. Alphonso. Intl Symp Balanced Fertilization., 2:446-48.

Menzel C M and Simpson D R (1987) Lychee Nutrition; a review. ScientHort., 31: 195-224.

Menzel K and Kirby E A (2001) Principles of Plant Nutrition. Pp 685. International Potash Institute, IPI, Bern, Switzerland

Pathak P K and Mitra S K (2010) Rate and time of potassium fertilization influence yield and quality of litchi. ActaHort863: 235-42.

Pathak P K, Majumdar K and Mitra S K (2013) Levels and time of potassium fertilization influence soil and leaf nutrient composition and its relation with yield of litchi. Indian J Hort., 69: 33-38

Singh V P, Kumar G and Singh A K (2007) Effect of water soluble fertilizer 'Polyfeed' on physicochemical attributes of litchi fruits cv. Rose Scented. Prog Agric., 7: 22-24.

Taiz Z and Zeiger E (2004) Plant Physiology. Pp 23-45. Porto Alegre, Artmed.

Trevisan, Senoo T, Uno T, Sasabe $\mathrm{Y}$ and Tada M (2006) Distinction of astringency in peach fruit using nearinfrared spectroscopy. Hort Res., 6: 137-43.

Wang Y, Wang $\mathrm{H} \mathrm{C}, \mathrm{Hu} \mathrm{Z}$ Q and Zhou Z K (2010) Litchi good for heath from skin to heart: An overview of litchi functional activities and compounds. ActaHort., 863: 644-45.

Yang S U, Xiao-Chao Zhou, Dan Gao O and Zhou K B (2015) Effects of the changes in the contents of $\mathrm{K}, \mathrm{Ca}$ and $\mathrm{Mg}$ in pericarp on the pericarp's coloring of Litchi chinensis cv. Ziniangxi. J CNKI., 33:12-17.

Yang B, Wang J, Zhao M, Liu Y, Wang W and Jiang Y (2006) Identification of polysaccharides from pericarp tissues of litchi (Litchi chinensis Sonn.) fruit in relation to their antioxidant activities. Carbohydrate Res., 341:634-38.

\section{How to cite this article:}

Karanjeev Kumar, Kumari Madhumala, Sanjay Sahay and Feza Ahmad. 2020. Response of Different Sources of Potassium on Biochemical Quality of Litchi cv. Deshi. Int.J.Curr.Microbiol.App.Sci. 9(02): 2281-2290. doi: https://doi.org/10.20546/ijcmas.2020.902.258 